\title{
Chapter 7 \\ Conclusions
}

\subsection{Introduction}

Millions of undocumented migrants live in the EU, and many more live in the countries outside of it. They have become undocumented through various circumstances: some have entered a country without the legal right to do so and continued to live in this new country; others have entered the country legally, but stayed there after their legal right has expired; and some babies are born undocumented. Undocumented migrants are also called irregular, paperless, sans-papiers, unauthorised, or even illegal migrants (Anderson and Ruhs 2010). They differ from each other in details, but the common factor is that they reside in a country without the proper legal right to do so and their presence is not fully approved by that country's authorities. Many of them are asylum-related migrants (i.e. they left their country of origin to seek safety in the EU). For many, the asylum request is a tool that makes their initial entry into the EU possible, but others do not bother to start the asylum process, because the majority will not receive asylum, subsidiary protection, or, in general, any kind of residence permit in the EU. The reasons for them leaving their countries of origin vary; however, these assorted reasons often do not give them the right to be internationally protected (see Jauhiainen et al. 2019).

Triandafyllidou and Ricard-Guay talked about a general lack of historical awareness, whereby 'hard territorial and digital borders and the whole administrative apparatus of passports and visas and different migration categories are rather recent phenomena, compared to the age-long nature of human mobility' (Triandafyllidou and Ricard-Guay 2019: 115). Furthermore, during 2020, because of the COVID-19 pandemic, many European countries established temporary lockdowns and states of emergency, which limited the opportunities for people to cross borders and request asylum (Jauhiainen 2020), and also created particular obstacles in the everyday lives of undocumented migrants. In some countries (such as in Hungary and Greece, at least temporarily) openly hostile opinions were expressed, and repressive actions taken, regarding asylum seekers and undocumented migrants. 
Nevertheless, irregular migration is a common contemporary phenomenon around the world (see Gonzales et al. 2019). Undocumented migrants are forced to live fully or partly outside the common societal systems that ordinary citizens enjoy. They often experience racism (Sigona 2012) and, with increasing frequency, attacks from far-right parties (Muis and Immerzeel 2017; Vieten and Poynting 2016). In the 2010s, many countries became stricter towards irregular migration and undocumented migrants, especially after the arrival of large numbers of asylum seekers in the EU in 2015. Many countries overruled international treaties and agreements and became more nationalistic in their migration-related policies (Brekke and Staver 2018; Niemann and Zaun 2018), some to the extent of totally stopping the arrival of asylum seekers (fearing that they would become undocumented migrants), as the situation in Greece at the EU border in 2020 illustrated (Jauhiainen 2020; Jauhiainen and Vorobeva 2020). Furthermore, the detention of asylum seekers and rejected asylum seekers has become a tool of stricter immigration policies (Könönen 2020).

Thresholds of inclusion and exclusion are continually renegotiated. Even policies that aim to include migrants may have the drawback of ultimately exposing these people to a negative social and legal super-visibility (Brighenti 2010), especially with regard to far-right parties, which might then activate repressive mechanisms (Tervonen et al. 2018) and further restrict their opportunities for action. The abovementioned changes also include Finland (Jauhiainen 2017; Saarikkomäki et al. 2018); however, as shown in recent decades, no countries have succeeded in expelling all undocumented migrants, so the political wishes to 'deport them all' cannot be enforced (Ambrosini 2017).

For this book, we studied undocumented migrants in Finland using quantitative surveys and ethnographic participant observation conducted among them. Furthermore, we asked about local authorities' practices and gathered experts' and workers' perspectives on undocumented migrants. By triangulating the data and using mixed methods, we were able to study undocumented migrants in Finland, their everyday lives, and their broader concerns. From this empirical research and data analysis, broader concepts relating to irregular migration emerged: the agency of undocumented migrants, who manage to make ends meet despite the hardships, continually finding new and 'creative' ways to survive; the creation of semi-legal spaces, whereby the clear-cut and rigid definitions legal/illegal, regular/irregular, documented/undocumented, applied by immigration policies, are challenged by the everyday lives and practices of these people; and their position outside civil society but, at the same time, 'inside' it, testing its predefined rules and regulations. In addition, we studied their aspirations, particularly in relation to their journeys to and within Finland, and determined their desire for on-migration from Finland to other countries, including returns to their countries of origin. Furthermore, we paid attention to the internet and social media, specifically considering how the digital divides shrink along undocumented migrants' journeys, how they build and maintain both strong and weak ties through these tools, how they use them, and how they are affected by them.

Conducting research about undocumented migrants is challenging everywhere; however, in countries with small populations (and especially low numbers of people 
with foreign backgrounds) such as Finland, it is even more challenging, since undocumented migrants are few and their need to invisibilise themselves is compelling: they might be more easily spotted and pointed out as 'the different ones' (by the police, but also by suspicious ordinary people). They 'experience the violence of being depicted as undocumented and are therefore liable to deportation and exclusion' on a daily basis (also facing the risk of ethnic profiling; Keskinen et al. 2018). Nevertheless, they 'also resist such impositions in their day to day lives' (Villegas 2010: 148). Considering all these elements, finding them, and winning and maintaining their trust, was an endeavour that, on the researchers' side, required time (months), dedication, strong ethical commitment, and profound caution.

As stated in the introduction to this book, and as many scholars have already recognised, being and becoming an undocumented migrant is not a clear-cut, definite status. The concept is such that it includes in-becoming situations and real-life circumstances, whereby the line separating a documented from an undocumented person is far from apparent. In Finland, the legislation and administrative practices are clear-if a person is an undocumented migrant, then he/she is in Finland illegally, should leave the country, and should have very limited rights, including no right to work. The legal definition of an undocumented migrant is clear-cut, even though it does not correspond with the everyday lives of these people or their understanding of their situations; for example, minors of a certain age have a right to attend school and an obligation to follow the basic education syllabus, but these children often cannot attend school, because of difficulties with transportation; the risk of exposing the parents to the authorities; or cultural issues, such as having both male and female children in classes together, or girls needing to travel alone to the school. Similarly, access to emergency healthcare services is legally available to everyone in Finland; however, in practice, many undocumented migrants are unable to use healthcare services, even in emergency cases, for different social, economic, and cultural reasons. We could present examples of 'exceptions to the rule' but, despite all efforts to define and frame who is classed as an undocumented migrantand this is valid, not only in Finland but, we dare say, in every country hosting them - the definition is bound to fail, and can be proven wrong by simple examples drawn from the everyday lives of these people. Overall, with this book, we have tried to give voices to the migrants themselves, since it often happens that analytical or too-theoretical approaches, while providing valuable insights, 'do not adequately capture the multifaceted and dynamic nature of migration processes, including from migrants' perspectives' (McAuliffe and Koser 2017: 7).

Regarding the practices concerning undocumented migrants, there are more commonalities between Finland and a number of Eastern European countries, where there are few of them and their rights are limited, due to tight legislation, than between Finland and many Western European countries, such as Germany, Sweden, France, Italy, the pre-Brexit UK, or the US: 'In contrast with older European Union member states, Eastern European states did not have significant numbers of residents with Middle Eastern, African or Asian background and were determined to keep it that way' (Dzenovska 2016: 2). Moreover, 'overall, the least permissive integration policies are predominantly found in Eastern Europe' 
(Schlueter et al. 2013: 675). We are not saying that the situations of undocumented migrants are the same in Western and Eastern European countries, suggesting a homogeneity between these countries; instead, it is of the utmost importance to recognise specific contexts, and the differences that emerge from them, when conducting studies about undocumented migrants and their everyday lives (McAuliffe and Koser 2017). This also means reflecting critically on theories regarding undocumented migrants-in particular their citizenship, agency, and individual-state relationships-and their applicability to various specific contexts. These concepts and their applicability (or the recognition of empirical instances of these concepts in fieldwork) can significantly change according to the context. In the case of Finland, studying manifestations of agency or the creation of semi-legal spaces presents obstacles in terms of the difficulty of conducting the fieldwork.

As mentioned, there are only a few thousand undocumented migrants in Finland and most of them are in hiding. On the one hand, it is not easy to find them and build relationships of trust with them; on the other hand, it is easier to gain both broad and general, as well as in-depth, understanding about them than in countries where there are hundreds of thousands of such people. The numbers of undocumented migrants in the whole of Finland are lower than they often are in a single large city in Western and Southern Europe. Furthermore, the key stakeholders and mediators are easier to find in Finland and, while in the field, it is easier to gradually grasp the big picture. Furthermore, despite the fact that the legislation in one country (such as Finland) sets the general rules for undocumented migrants in its own territory, research has demonstrated that their situations differ everywhere, even in Finland. Different migrants may thus be able to live different everyday lives and have different practices in each urban context; hence, proper contextualisation of concepts and theories needs to be applied, not only to different countries and locations, but also across undocumented migrant populations in the same country.

In Sect. 7.2, we present the main findings of the research, focusing mainly on Finland, which was our empirical case; however, the results can also be applied to the broader EU context and beyond. The many processes, challenges, and opportunities undocumented migrants face in Finland are, in some respects, similar to the ones they face in other EU member states, especially the smaller countries (in particular in the aforementioned Eastern European member states). There are also, however, particularities in each society, with regard to the legislation and the environment, that cannot be ignored when addressing the issues of undocumented migrants and irregular migration. Generalisations are difficult, if not too risky, to make in this field of study. In this sense, contextualisation remains very important concerning the use of specific terms, concepts, and theories, because the differences in contexts mean that the same concepts do not fit everywhere-starting with the very definition of an undocumented migrant. In this book, we have aimed to provide links to wider contexts and general concepts, while remaining as true as possible to the specific case of Finland. Finally, in Sect. 7.3, we discuss the novelty of our findings and suggest the most promising research themes we identified from our study. 


\subsection{Main Results}

One significant result of this research was the need to study, in depth, the contexts of undocumented migrants, not as static elements, but rather in their evolution and 'becoming'. Conducting a context-specific case study about undocumented migrants, as we did in Finland, reveals how difficult it is to directly transfer and apply general theories and concepts regarding them, and how those theories and concepts can become contested sites between authorities, migrants, and ultimately researchers, who are trying to make sense of a phenomenon that can hardly be classified and categorised. As shown in the introduction, this difficulty stems from the very concept of an undocumented (or irregular) migrant:

There is a wide range of definitions of 'irregular' migrants, including those who have purposefully crossed a border without authorisation, those who have inadvertently or unknowingly crossed a border without authorisation, those who have become irregular sometime after entering a country regularly, those who have been trafficked, and those who have been born into irregularity (McAuliffe and Koser 2017: 3-4).

As evidenced throughout the book, and discussed previously, no universal categories of undocumented migrants fit all contexts and individuals. This creates friction between the authorities, who need to have clear-cut categories and definitions that best fit this population; the migrants themselves, who often do not know their legal status, or how they can change it; and researchers, who try to identify recurrent patterns and generalizable concepts and theories. Indeed, any undocumented migrant could have belonged to several categories during his/her asylumrelated journey to the EU and Finland. He/she has been (and is) a citizen of his/her country of origin, with all rights to reside there. During the journey, he/she might have gained the status of temporary protected person (e.g. from the UNHCR and the national government, as is the case with Syrians in Turkey). Later, he/she might have been an asylum seeker in the EU and, in specific cases, also had the right to reside in Finland through its asylum process. Finally, he/she might have become an undocumented migrant in a given country because he/she failed the asylum process and/or did not obtain a residence permit there. It is thus not who an undocumented migrant is, but who they are (plural), and the ways in which they are defined, that have consequences for their everyday lives, while remaining contradictory and ambiguous, even for themselves.

The category 'undocumented migrants' thus includes many kinds of people, from children to elderly men and women, illiterate people and those with university degrees. Among them are people originating from dozens of different countries. 'Embodying' different legal categories along their asylum-related journeys, and during and after the asylum processes, it is no wonder that many current undocumented migrants cannot properly understand and define their legal status or the stage they have reached in the legalisation process. Such complexity and blurring of externally and politically constructed categories should be reflected in both policies and research regarding undocumented migrants, because such categories 'serve to perpetuate and reinforce a simplistic dichotomy which is used to distinguish, divide 
and discriminate between those on the move' (Crawley and Skleparis 2018: 52). As mentioned, these categorisations become contested sites between authorities, migrants, and the researchers who are trying to make sense of the patterns that they study.

States, which need clear-cut (albeit unrealistic) categories and taxonomies, significantly influence the construction of the identities of undocumented migrants (Koopmans et al. 2005), obliging them to wear different masks according to each country's legal requirements (Mountz et al. 2002; Papadopoulos and Tsianos 2008). Ultimately, these people often acquire multiple identities and masks, which are necessary for their survival. The ones who are not flexible enough to adapt (Ong 1999), or do not exercise their agency by creating semi-legal spaces for themselves, are the ones most at risk of being exploited or being caught by human trafficking networks.

Every country has a variety of undocumented migrants, but also particularities in their nationalities. This might be due to the geographical nearness of the countries from which many came or historical legacies of colonialism. In Finland, one particularity is the large number of youngish male Iraqi nationals among undocumented migrants. As discussed, most of them arrived in the summer and autumn of 2015 as asylum seekers. They failed the asylum process, mainly because of sudden changes in the Finnish asylum and immigration policies and their implementation (Saarikkomäki et al. 2018); however, they did not return to their country of originmany due to obvious danger. Many Iraqi undocumented migrants (who actually have been 'documented' during their stay in Finland) cannot be removed from Finland to Iraq because they do not have the proper documents for international passage and the Iraqi authorities refuse to take them back. At the same time, they do not have the right to reside in Finland. In such a legal limbo, in-between categories, and unable to legally either leave or stay, they have become undocumented migrants. Such a limbo is common in many EU member states, although the rights of such non-deportable people vary; for example, in Germany, these people can and must extend and renew their 'tolerated' presence regularly with the authorities, and they have the right to be employed. This may open for them the possibility of legalising their residence (Jauhiainen et al. 2019); however, so far, this has not been possible in Finland, even though the Government of Finland plans to review such a possibility (Government of Finland 2019).

Another key finding concerned the complexity of the journeys of the undocumented migrants (i.e. during which they became undocumented). They used multiple modes of migration, but irregular mixed migration prevailed as a reason for them becoming undocumented migrants. Many pushing and pulling factors (van Hear et al. 2018) bring these people to Finland, or to other EU member states, and make them decide to remain there as undocumented migrants. Some factors relate to the asylum- and work-related requirements, while others do not. Many current undocumented migrants fled from their country of origin due to external factors that created insecurity for them. Indeed, many left because of political reasons, conflicts, persecution, and even war. Poor livelihood opportunities often prevailed at home, and they perceived better work opportunities in their destination - the EU, and in the 
specific case of this book, Finland. Regarding the undocumented migrants we studied in Finland, very few had social pulling reasons to move, such as friends or family members in Finland. Some were lured into the country by misinformation about the ease of legalising their presence in Finland, receiving abundant social benefits, or having plenty of work opportunities in the country. Widespread rumours and misinformation in social media and in personal networks have serious (often underestimated, or insufficiently explored) material consequences for the movements of these people, adding to their already very complex aspirations, motivations, decisions, and actions on the move (Carling and Collins 2018; Thulin and Vilhelmson 2016).

Another significant finding related to the production of undocumented migrants through very complex asylum processes-an observation particularly relevant for Finland, but also for other EU member states. The migrants were often not aware of the details of the process and did not realise what stage they had reached, what their rights and duties were, or the consequences of the narratives they presented during the process. Sometimes the reasons for fleeing their country of origin were compelling enough to justify asylum or a residence permit in a given country, but the asylum seekers were not able to express these reasons in ways that would convince the authorities. After being rejected, some appealed to the courts and perhaps submitted subsequent asylum applications, but the majority finally failed the asylum process and became undocumented migrants. In Finland, therefore, one particularity is that many current undocumented migrants have been 'known' by the national and local authorities during their asylum processes (i.e. they have been registered and have been in contact with these authorities).

During the fieldwork, we recognised how often undocumented migrants' personal conditions (in terms of trauma, memory loss, or anxiety) contributed to their failure of the asylum process. There are 'connections between emotions and the way that policies are implemented', as Gill (2016: 143) highlighted in respect of the British asylum system. In addition, if a person perceives that his/her opportunities (sometimes literally a matter of life or death) would be better in Finland (or another EU member state) than in the country of origin, he/she will try to remain in the new country, even as an undocumented migrant, as our study, alongside other studies, indicated. In general, very few of the studied undocumented migrants left Finland or the EU after failing the asylum process, despite the hardships they encountered in their everyday lives.

After 2015, in many EU member states, right-wing political parties argued for stricter immigration policies, including those regarding asylum seekers and undocumented migrants (Brekke and Staver 2018). Despite attempts to harmonise migration and asylum policies at the EU level, and create an integrated management system and European administrative body to deal with the asylum processes (see, for example, Kaunert and Léonard 2012), they remained incomplete in the early 2020s. Many EU member states have been reluctant to give such decision-making powers to EU organisations; hence, asylum-related practices are implemented differently in different EU member states, illustrating a lack of solidarity between those member states, which creates particular challenges for asylum seekers (and 
undocumented migrants to some extent) (Scipioni 2018). Such disparity in the policies regarding asylum seekers and undocumented migrants, and the differences in how these policies are implemented, mean that the treatment of undocumented migrants differs depending on where they reside in the EU. Having seen the pace of development in the EU in recent years, necessary consensus and agreement over the Pact on Migration and Asylum proposed by the EC in 2020 (European Commission 2020) is unlikely to be reached. Furthermore, this policy renewal suggestion has certain aspects that could make the asylum process ever harder for asylum seekers, thus not necessarily reducing the number of undocumented migrants in Europe.

Another important issue that emerged in our study was the need to pay attention to the broad spectrum of the everyday lives of undocumented migrants. Disparities within the EU (and beyond it) make it very important to study, in depth, their contexts-a topic often overlooked because of challenges in obtaining information about and from undocumented migrants. In Finland, the large number of undocumented migrants is a rather new phenomenon; therefore, the administrative and enforcement practices have not yet been consolidated by the central and local authorities. Few authorities know much about undocumented migrants' everyday lives. Such a situation creates an obvious demand for authorities to receive more information about these migrants' situations; however researchers must be very careful not to reveal the few safe places and semi-legal spaces (such as employment) that these migrants have struggled to create for themselves in their everyday lives, despite the tight regulations.

In general, like many of us, undocumented migrants want to live normal everyday lives, but only a few are able to do so. They try to sleep in a secure place, wake up there, go to work, spend time with family and friends, communicate on social media, and then go to sleep again:

\footnotetext{
Window shopping, playing football or video games, surfing the internet, talking on the phone, visiting friends, having a barbeque, walking in a park, going to church or community organisations, going to the pub for a drink after work and sometimes to nightclubs [were] the most common activities mentioned by interviewees (Sigona 2012: 56).
}

However, for the majority of undocumented migrants we met in Finland, everyday life consisted of continual survival challenges that had to be overcome, such as avoiding being spotted by the police (or by far-right organisations); carefully choosing the public spaces where they could be present, but remain largely invisible; enduring exploitative working conditions; coping with severe psychological stress due to their precarious living conditions and past traumas (see Herlihy et al. 2012); not having a proper 'home', but instead needing to frequently change the places where they slept; and balancing the need for a social network with the necessity of hiding their irregular condition from new acquaintances. They always had to hide in the shadows and margins of society. Intermediaries (NGOs, private citizens, the church, and their own ethnic groups) often enable undocumented migrants to ultimately make ends meet in a country (Ambrosini 2017): 'Pro-migrant groups from within the majority society take up the cause of these immigrant groups' (Koopmans et al. 2005: 83-84). This was the case in Finland, even though these 
intermediaries were often replaced by the migrants' own networks, if they were able to build them.

A major concern of undocumented migrants' everyday lives is how to sustain themselves. This issue emphasises undocumented migrants' agency, as well as their capacity to create semi-regular spaces for themselves, despite the hardships. In Finland, the majority of undocumented migrants would like to work, but the law does not allow them to do so; nevertheless, one out of four was employed. They crossed the line of legality, because they did not have residence or work permits, but undocumented migrants in Finland inevitably need money to pay for accommodation, food, clothing, mobile phones, internet access, and various other everyday needs. Their jobs might not be illegal as such, but the conditions of work, salaries, and other issues usually are. If there is no alternative, some undocumented migrants turn to semi-legal or illegal activities to survive. In principle, many refuse to do this, despite the hardships they undergo in their everyday lives: many want a regular job, and we met a few who eventually returned to their countries of origin, because they did not want to break the law. Precarious, underpaid (or unpaid), and exploitative working conditions are not confined only to undocumented migrants - in fact, they are deeply rooted in our society; hence, they need to be reflected upon, and concrete actions ought to be taken: 'Informal and precarious work is not only confined to undocumented workers and should not be understood as a marginal phenomenon, but rather as central to the organisation of the labour market in the global neo-liberal order' (Sager 2015: 125).

Health is a crucial everyday issue for everyone, including undocumented migrants, and access to healthcare is sometimes a matter of life and death. Finland appears to be among the EU member states guaranteeing only very limited access to healthcare for undocumented migrants. Access to emergency services is provided for everyone who happens to be in Finland; however, the non-EU residents and non-residents have to pay for these services. Some Finnish municipalities have decided to offer other necessary healthcare services; however, undocumented migrants are expected to pay for these services. Some NGOs help them with healthcare and other everyday needs, including accommodations, clothing, language, and legal aid; however, many undocumented migrants are afraid to use these services, do not know about them, or do not want such help because they consider it to be humiliating, especially when they are fit, working-age men or women with many skills. Healthcare systems are strongly linked with immigration policies and, therefore, with legal and registered residence in a country (Martinez et al. 2015). Non-registration in the system (this is particularly true for Nordic countries, where the welfare states are pervasive and highly personalised) prevails over undocumented migrants' actual health needs, making them afraid of visiting hospitals, to avoid being questioned about their residence by healthcare professionals (Bendixsen 2018): 'Institutional prejudice and discrimination as well as cultural differences were also reported by undocumented immigrants deterring them from seeking and receiving needed services' (Martinez et al. 2015: 964).

Health-related issues can change rapidly and profoundly, having a crucial impact on undocumented migrants — as the COVID-19 pandemic, which emerged in 2020, 
showed. In many countries, the state versus individual relationships changed abruptly and dramatically. As a vulnerable group, undocumented migrants are often the people who suffer the most from these changes, especially if they touch the rights of citizens due to exceptional circumstances. As Collins noted:

\footnotetext{
While most governments have permitted the return of citizens and those with long-term residence rights, the fate of irregular migrants, asylum seekers, refugees and guest workers has been quite different. Irregular migrants find the conditions of survivability upended by new restrictions while they have no access to resurgent state responses (2021:3).
}

In 2020, Finland, like many other countries around the world, suddenly experienced a lockdown and general state of emergency (due to prevention measures to stop the spread of COVID-19), under which the basic rights of all residents were substantially restricted. In many countries, mobility in public spaces became severely restricted, and many shops, restaurants, and other facilities were closed. Social distancing was required, often by law, and this was a problem for many undocumented migrants, especially those who lived tightly packed in others' houses and could not afford a place of their own: 'This pandemic has made us rethink our relationships with our bodies, not only in relation to space, but also in relation to other bodies' (Tedeschi 2020: 181) and with the law. In addition, many undocumented migrants lost their precarious jobs, creating an acute financial problem for them, since they continued to remain outside the society's official support networks. Combined with the already existing challenges in accessing the healthcare, such exceptional circumstances created an additional burden for undocumented migrants, who in most cases were not informed and protected like the 'official' citizens. Again, Collins sharply noted that we are facing a nationalist centring of the state, whereby 'whether in purportedly competent or incompetent, progressive or regressive state responses, it is "our" citizens that have been favoured and migrants of all kinds who have been deemed disposable' (2021: 4). In Finland, migrants who were afraid or unable to contact or visit healthcare service points, despite COVID-19 symptoms, posed risks for themselves and the people with whom they were in contact (i.e. often, but not only, other undocumented migrants). The NGOs helping undocumented migrants had to suspend their activities or provide the services only by phone or email. In these circumstances, many undocumented migrants in Finland had no proper institutional help. By contrast, to more effectively deal with the spread of the pandemic, Portugal (Drury 2020) and Italy (Testore 2020) implemented temporary regularisation measures for some undocumented migrants, and Spain made one of its permanent regularisation mechanisms more accessible (PICUM 2020). The impacts of the measures against the COVID-19 pandemic affected, not only health, but the rights of citizens and non-citizens.

Finally, but importantly, a significant topic we addressed was the use and impact of the internet and social media. Access to the internet and the use of social media were lifelines for the undocumented migrants. They could stay in contact with their families, and old and new friends, through these tools; thus individuals in Finland, and their families and friends, could receive (at least temporary) psychological consolation and security, as already highlighted by Sigona (2012: 58): 
There is ... another place where young undocumented migrants feel secure - the internet. Social networking sites (more often in their first language than in English), Skype, emailing and instant messaging are important components of the daily life of several interviewees, especially the younger ones.

The majority of undocumented migrants used the internet and social media for functional purposes, such as searching for employment, accommodation, and opportunities in other towns in Finland; to follow events in their countries of origin; and to learn the local language. In general, the first and second digital divides (i.e. access to the internet and the ability and resources to use the internet and social media) had narrowed among the undocumented migrants since their departures from their countries of origin (see also Merisalo and Jauhiainen 2020); however, in some of their countries of origin, these media were not yet ubiquitous, meaning that their family and friends did not have easy-or necessarily any-access to the internet. These tools could not cover all aspects of social networking; hence, a few undocumented migrants used ordinary telephone calls to their countries of origin. The internet and social media were also littered with fake news and misinformation that, while initially attracting them, ultimately caused discomfort, risks, and disappointment. In addition to the usual security risks (e.g. the police being able to trace undocumented migrants through their mobile phone use), there were migrants who wanted to forget about their home countries (because of traumatic experiences, or due to other personal reasons) and cut their ties with it. The 'intrusiveness' and 'pervasiveness' of these technologies in their everyday lives thus hindered, not only the right be forgotten, but also the right to forget.

\subsection{Suggestions for Research}

We include here suggestions and topics for further research as indicated by questions left open by our study and its findings. At the moment, a challenging topic that requires further research is that no one seems to know how many undocumented migrants are in the EU and its member states. Our own estimation of the number of undocumented migrants in Finland clearly indicated the various challenges researchers have to overcome to make a correct estimation. In general, recent European estimates (see Pew Research Center 2019) have been rough and have perplexed many scholars and stakeholders concerned with irregular migration, who, however, at the same time have not been able to obtain or provide accurate data. Without systematic analysis, the issues regarding undocumented migrants rest on wild speculations, and such (potentially exaggerated) numbers and issues can be used for political purposes, to create anxiety in EU member states and encourage ungrounded policy measures.

From our research, other detailed topics emerged that require more in-depth research. These include, for example, the following: the connection between undocumented migrants' knowledge of local language, employment, and integration; how information and misinformation on the internet and in social media influence 
undocumented migrants' decision-making and migration patterns (based on the definition of connected, rather than physical, migration routes; Sánchez-Querubín and Rogers 2018); undocumented migrants' access to psychological healthcare in the EU member states; undocumented migrants' connections to individual, community, and national security; the immobility of undocumented migrants from the perspective of post-migration studies; the agency of undocumented migrants; the methodological challenges of conducting research about and with undocumented migrants, such as comparative methodological studies across various countries; and alternatives to overcome what Crawley and Skleparis (2018) called 'categorical fetishism' in migration research and policies. The last point is especially important: more research and clarification is needed of the terminology used to refer to undocumented migrants (e.g. irregular migrant, illegal migrant, sans-papiers, unauthorised migrant, etc.). More appropriate concepts, illustrating the in-between categories and definitions of the everyday lives of these people, and the relevance and variety of the contexts in which they live, are needed in the 2020s to support legislation and policymaking regarding migration-related issues. Of great importance is the need to provide clear research- and evidence-based open-access information about the various everyday life issues of undocumented migrants in their native languages, which could be incorporated into books - an attempt we made with this publication, which unfortunately failed due to reasons outside our control. On the other hand, we will make sure that at least the people most concerned with undocumented migrants (i.e. interviewees from municipalities, NGOs, and similar), whom we met, have access to this book.

Regarding other topics that emerged from the findings of our study, among others, the connection between undocumented migrants' knowledge of the local language, employment, and integration could open up interesting lines of research. Undocumented migrants who know the local language usually have more opportunities to integrate into the local community (and possibly find a job) than others who do not have this knowledge. Means of integration are (potentially) also the internet and social media, whereby undocumented migrants, who cannot freely visibilise themselves in public spaces, can anonymously navigate the internet and find information about housing, employment, education, etc. Internet and social media fake information can, however, mislead them and potentially lead to further segregation, rather than integration, by negatively influencing the migrants' decisions in their everyday lives.

Worthy of further research and study, also, is migrants' access to psychological healthcare in the EU member states. As explained in Chap. 5, our research findings showed how undocumented migrants often suffer from stress, anxiety, and mental disorders; however, at least in Finland, the healthcare system does not deem mental issues to require the emergency services provided for these people. Undocumented migrants' mental health conditions should not be ignored, isolated, or considered separately from the official welfare state, but should be dealt with systematically through forward-looking, proactive policies and practices aiming to prevent unwanted consequences for them and the society in which they live. The impact of the COVID-19 pandemic on the geographies of migration flows in general, and on 
the undocumented migrants' overall position in society, including the changes in their everyday lives (which may last for years), is a topic that requires proper scrutiny.

Conducting this research was methodologically challenging, as were the ethical issues that dealing with such a vulnerable group inevitably involves. In Chap. 2, we presented our choice to use mixed methods to study the everyday lives of undocumented migrants; however, we believe that in-depth analyses of appropriate (or new, even experimental) methodologies for studying a social phenomenon such as irregular migration, with its characteristic of continuous becoming, its lack of clear-cut definitions, categorisations, and of its varied population, are still greatly needed. Furthermore, a systematic, representative longitudinal study of undocumented migrants in all EU member states, including Finland, would be helpful. A large and weighted-sample annual or biannual survey conducted among undocumented migrants in all countries might be an option. The survey should be supplemented with in-depth interviews on regular and novel topics. These data should be as open as possible for researchers, policymakers, the media, and anyone interested in drawing research- and evidence-based conclusions. Obviously, there should be a very strong emphasis on research ethics in both the collection and use of the data.

Finally, research on asylum and migration policy failures is also needed, as well as constructive proposals for moving forward towards better policies. As our research and former studies indicated, undocumented migrants are a reality in all countries, and no countries have been able to expel all undocumented migrants (see Ambrosini 2017), even when resorting to strong measures. The policymakers and policies should take this as a fact and consider how to reorganise society so that undocumented migrants can contribute to it (see Castles 2004). While strict immigration and asylum policies are being implemented, the population in the EU is ageing, and the labour force and the EU's global economic impact are declining. Finland is among the countries where the proportion of people aged at least 65 years is growing fastest in the world, and every year the working-age population grows smaller (Eurostat 2019; Statistics Finland 2018; Teivainen 2017). Nevertheless, in recent years, millions of people in the EU (and tens of thousands in Finland) have tried unsuccessfully to receive residence and work permits in the EU member states through the asylum process. Part of the failure of the EU asylum policies and processes, including the Dublin Regulation, is due to legal immigration policies having failed, and new ones are urgently needed. A revision and functioning harmonisation of immigration and asylum policies in the EU are required, not only from human rights perspectives, but also because immigration to the EU and Finland is needed for the above-mentioned economic and demographic reasons. Unfortunately, as mentioned, it will be difficult to gain consensus in the EU on asylum and immigration policies and their implementation, and all proposals for asylum and migration policy renewal have to strike a balance between harder and softer solutions.

Finally, as anticipated in the introduction, we offer a few suggestions for the undocumented migrants in the EU, including Finland. This would require a lengthy and thorough discussion, but we present the suggestions briefly. Perhaps the main 
recommendation for them is not to give up the hope that they will be legalised and can have meaningful lives in the countries in which they live. It is important for undocumented migrants to learn about the language, culture, and people of that country, and show in concrete ways how they can contribute, positively, to the communities they have become part of, thus eventually moving out of the shadows and margins into the shared societies of the countries in which they reside.

\section{References}

Ambrosini, M. (2017). Why irregular migrants arrive and remain: The role of intermediaries. Journal of Ethnic and Migration Studies, 43(11), 1813-1830.

Anderson, B., \& Ruhs, M. (2010). Researching illegality and labour migration. Population, Space and Place, 16, 175-179.

Bendixsen, S. (2018). The politicized biology of irregular migrants: Micropractices of control, tactics of everyday life and access to healthcare. Nordic Journal of Migration Research, 8(3), 167-174.

Brekke, J., \& Staver, A. (2018). The renationalisation of migration policies in times of crisis: The case of Norway. Journal of Ethnic and Migration Studies, 44(13), 2163-2181.

Brighenti, A. (2010). Visibility in Social Theory and Social Research. Basingstoke/New York: Palgrave Macmillan.

Carling, J., \& Collins, F. (2018). Aspiration, desire and drivers of migration. Journal of Ethnic and Migration Studies, 44(6), 909-926.

Castles, S. (2004). Why migration policies fail. Ethnic and Racial Studies, 27(2), 205-227.

Collins, F. (2021). Migration ethics in pandemic times. Dialogues in Human Geography, 11(1), 78-82.

Crawley, H., \& Skleparis, D. (2018). Refugees, migrants, neither, both: Categorical fetishism and the politics of bounding in Europe's 'migration crisis'. Journal of Ethnic and Migration Studies, 44(1), 48-64.

Drury, C. (2020). Coronavirus: Portugal to treat migrants as residents during pandemic. Independent. Available at: https://www.independent.co.uk/news/world/europe/coronavirus-portugalmigrants-asylum-seekers-treatment-residents-a9431831.html. Accessed 1 Apr 2020.

Dzenovska, D. (2016). Eastern Europe, the moral subject of the migration/refugee crisis, and political futures. Near Futures Online, 1, 1-13.

European Commission. (2020). Communication from the Commission to the European Parliament, the Council, the European Economic and Social Committee and the Committee of the Regions on a New Pact of Migration and Asylum. COM/2020/609 final.

Eurostat. (2019). Population structure and ageing. Available at: https://ec.europa.eu/eurostat/ statistics-explained/index.php/Population_structure_and_ageing. Accessed 17 Sept 2019.

Gill, N. (2016). Nothing personal? Geographies of governing and activism in the british asylum system. Chichester: Wiley.

Gonzales, R., Sigona, N., Franco, M., \& Papoutsi, A. (2019). Undocumented migration. Borders, immigration enforcement, and belonging. Cambridge: Polity Press.

Government of Finland. (2019). Inclusive and competent Finland - a socially, economically and ecologically sustainable society. Programme of Prime Minister Antti Rinne's Government 2019. Helsinki: The Prime Minister's Office.

Herlihy, J., Jobson, L., \& Turner, S. (2012). Just tell us what happened to you: Autobiographical memory and seeking asylum. Applied Cognitive Psychology, 26, 661-676.

Jauhiainen, J. (Ed.). (2017). Turvapaikka Suomesta? Vuoden 2015 turvapaikanhakijat ja turvapaikkaprosessit Suomessa. [In Finnish, Asylum in Finland? Asylum seekers and asylum 
processes in Finland in 2015] Publications of the Department of Geography and Geology of the University of Turku 5.

Jauhiainen, J. (2020). Biogeopolitics of Covid-19: Asylum-related migrants at the European Union borderlands. Tijdschrift voor Economische en Sociale Geografie. (online first).

Jauhiainen, J., \& Vorobeva, E. (2020). Asylum seekers and migrants in Lesvos, Greece, 2019-2020. Publications of the Department of Geography and Geology of the University of Turku 15.

Jauhiainen, J., Eichholz, L., \& Spellerberg, A. (2019). Refugees, asylum seekers and undocumented migrants in Germany, 2019. The case of the Rhineland-Palatinate and Kaiserslautern. Publications of the Department of Geography and Geology of the University of Turku 13.

Kaunert, C., \& Léonard, S. (2012). The development of the EU asylum policy: Venue-shopping in perspective. Journal of European Public Policy, 19(9), 1396-1413.

Keskinen, S., Alemanji, A., Himanen, M., Kivijärvi, A., Osazee, U., Pöyhölä, N., \& Rousku, V. (2018). The Stopped - Ethnic Profiling in Finland. SSKH Notat 1/2018. Helsinki: Swedish School of Social Science, University of Helsinki.

Könönen, J. (2020). Legal geographies of irregular migration: An outlook on immigration detention. Population, Space and Place, 26, e2340.

Koopmans, R., Statham, P., Giuni, M., \& Passy, F. (2005). Contested citizenship: Immigration and cultural diversity in Europe. Minneapolis: University of Minnesota Press.

Martinez, O., Wu, E., Sandfort, T., Dodge, B., Carballo-Dieguez, A., Pinto, R., Rhodes, S., Moya, E., \& Chavez-Baray, S. (2015). Evaluating the impact of immigration policies on health status among undocumented immigrants: A systematic review. Journal of Immigrant and Minority Health, 17(3), 947-970.

McAuliffe, M., \& Koser, K. (Eds.). (2017). A long way to go. Irregular migration patterns, processes, drivers and decision-making. Canberra: ANU Press.

Merisalo, M., \& Jauhiainen, J. (2020). Digital divides among the asylum-related migrants: Comparing the internet use and smartphone ownership. Tijdschrift voor Economische en Sociale Geografie, 111(5), 689-755.

Mountz, A., Wright, R., Miyares, I., \& Bailey, A. (2002). Lives in limbo: Temporary protected status and immigrant identities. Global Networks, 2, 335-356.

Muis, T., \& Immerzeel, T. (2017). Causes and consequences of the rise of the populist radical right parties and movements in Europe. Current Sociological Review, 65(6), 909-930.

Niemann, A., \& Zaun, N. (2018). EU refugee policies and politics in the times of crisis: Theoretical and Empirical perspective. Journal of Common Market Studies, 56(1), 3-22.

Ong, A. (1999). Flexible citizenship: The cultural logics of transnationalism. London: Duke University Press.

Papadopoulos, D., \& Tsianos, V. (2008). The autonomy of migration: The animals of undocumented mobility. In A. Hickey-Moody \& P. Malins (Eds.), Deleuzian encounters. Studies in contemporary social issues (pp. 223-235). Basingstoke: Palgrave Macmillan.

Pew Research Center. (2019). Europe's unauthorized immigrant population peaks in 2016, Then levels off. Available at: https://www.pewresearch.org/global/2019/11/13/europes-unauthorizedimmigrant-population-peaks-in-2016-then-levels-off/. Accessed 14 Nov 2019.

PICUM. (2020). Non-exhaustive overview of European government measures impacting undocumented migrants taken in the context of COVID-19. March-August 2020. Brussels: Platform for International Cooperation on Undocumented Migrants (PICUM).

Saarikkomäki, E., Oljakka, N., Vanto, J., Pirjatanniemi, E., Lavapuro, J., \& Alvesalo-Kuusi, A. (2018). Kansainvälistä suojelua koskevat päätökset Maahanmuuttovirastossa 2015-2017: Pilottitutkimus 18-34 vuotiaita Irakin kansalaisia koskevista myönteisistä ja kielteisistä päätöksistä [In Finnish, Decisions on international protection in the Finnish Immigration Service in 2015-2017: Pilot study on positive and negative decisions for Iraqi citizens aged 18-34]. Oikeustieteellisen tiedekunnan tutkimusraportteja ja katsauksia 1/2018. Turku: University of Turku, Åbo Akademi and Yhdenvertaisuusvaltuutettu. Available at: https://www.utu.fi/sites/ default/files/public:/media/file/RPR_1_2018.pdf. Accessed 6 Mar 2021. 
Sager, M. (2015). Precarity at work: Asylum rights and paradoxes of labour in Sweden. In L. Waite, G. Craig, H. Lewis, \& K. Skrivankova (Eds.), Vulnerability, exploitation and migrants. insecure work in a globalized economy (pp. 115-128). London: Palgrave Macmillan.

Sánchez-Querubín, N., \& Rogers, R. (2018). Connected routes: Migration studies with digital devices and platforms. Social Media + Society, 4(1), 1-13.

Schlueter, E., Meuleman, B., \& Davidov, E. (2013). Immigrant integration policies and perceived group threat: A multilevel study of 27 Western and Eastern European countries. Social Science Research, 42(3), 670-682.

Scipioni, M. (2018). Failing forward in EU migration policy? EU integration after the 2015 asylum and migration crisis. Journal of European Public Policy, 25(9), 1357-1375.

Sigona, N. (2012). 'I have too much baggage': The impacts of legal status on the social worlds of irregular migrants. Social Anthropology, 20, 50-65.

Statistics Finland. (2018). Number of young people in danger of diminishing considerably due to the decrease in birth rate. Available at: https://www.stat.fi/til/vaenn/2018/vaenn_2018_201811-16_tie_001_en.html. Accessed 17 Sept 2019.

Tedeschi, M. (2020). The body and the law across borders during the COVID-19 pandemic. Dialogues in Human Geography, 10(2), 178-181.

Teivainen, A. (2017). Finland's shrinking working-age population a concern for experts. Helsinki Times 10.7.2017. Available at: https://www.helsinkitimes.fi/finland/finland-news/domestic/ 14881-finland-s-shrinking-working-age-population-a-concern-for-experts.html. Accessed 17 Sept 2019.

Tervonen, M., Pellander, S., \& Yuval-Davis, N. (2018). Everyday bordering in the Nordic countries. Nordic Journal of Migration Research, 8(3), 139-142.

Testore, G. (2020). Migrant regularisation in Italy: A contested measure. Available at: https://ec. europa.eu/migrant-integration/news/migrant-regularisation-in-italy-a-contested-measure. Accessed 20 Oct 2020.

Thulin, E., \& Vilhelmson, B. (2016). The iInternet and desire to move: The role of virtual practices in the inspiration phase of migration. Tijdschrift voor Economische en Sociale Geografie, 107 (3), 257-269.

Triandafyllidou, A., \& Ricard-Guay, A. (2019). Governing irregular and return migration in the 2020s: European challenges and Asian Pacific perspectives. Journal of Immigrant \& Refugee Studies, 17(2), 115-127.

van Hear, N., Bakewell, O., \& Long, K. (2018). Push-pull plus: Reconsidering the drivers of migration. Journal of Ethnic and Migration Studies, 44(6), 927-944.

Vieten, U., \& Poynting, S. (2016). Contemporary far-right racist populism in Europe. Journal of Intercultural Studies, 37(6), 533-540.

Villegas, F. (2010). Strategic in/visibility and undocumented migrants. In G. Sefa Dei \& M. Simmons (Eds.), Fanon \& education: Thinking through pedagogical possibilities (pp. 147-170). New York: Peter Lang Ag.

Open Access This chapter is licensed under the terms of the Creative Commons Attribution 4.0 International License (http://creativecommons.org/licenses/by/4.0/), which permits use, sharing, adaptation, distribution and reproduction in any medium or format, as long as you give appropriate credit to the original author(s) and the source, provide a link to the Creative Commons license and indicate if changes were made.

The images or other third party material in this chapter are included in the chapter's Creative Commons license, unless indicated otherwise in a credit line to the material. If material is not included in the chapter's Creative Commons license and your intended use is not permitted by statutory regulation or exceeds the permitted use, you will need to obtain permission directly from the copyright holder.

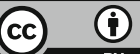

